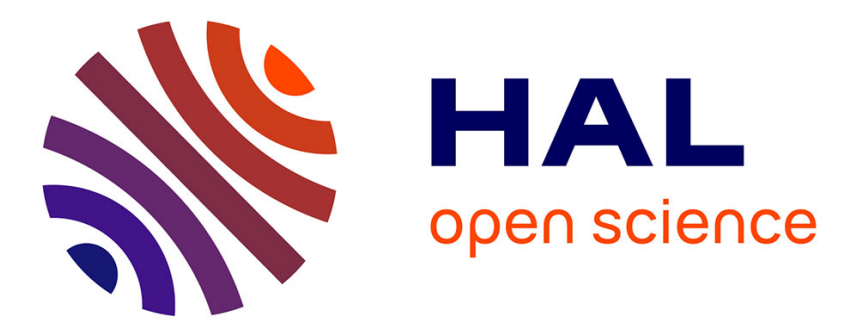

\title{
Structural investigations of native and oxidised LDL using X-ray and neutron solution scattering techniques
}

\author{
D. Meyer, A. Nealis, K. Bruckdorfer, S. Perkins
}

\section{To cite this version:}

D. Meyer, A. Nealis, K. Bruckdorfer, S. Perkins. Structural investigations of native and oxidised LDL using X-ray and neutron solution scattering techniques. Journal de Physique IV Proceedings, 1993, 03 (C8), pp.C8-257-C8-260. 10.1051/jp4:1993850 . jpa-00252281

\section{HAL Id: jpa-00252281 https://hal.science/jpa-00252281}

Submitted on 1 Jan 1993

HAL is a multi-disciplinary open access archive for the deposit and dissemination of scientific research documents, whether they are published or not. The documents may come from teaching and research institutions in France or abroad, or from public or private research centers.
L'archive ouverte pluridisciplinaire HAL, est destinée au dépôt et à la diffusion de documents scientifiques de niveau recherche, publiés ou non, émanant des établissements d'enseignement et de recherche français ou étrangers, des laboratoires publics ou privés. 


\title{
Structural investigations of native and oxidised LDL using X-ray and neutron solution scattering techniques
}

\author{
D.F. MEYER, A.S. NEALIS, K.R. BRUCKDORFER and S.J. PERKINS
}

Department of Biochemistry and Chemistry, Royal Free Hospital School of Medicine, Rowland Hill Street, London NW3 $2 P F, U . K$.

\section{ABSTRACT}

The gross structures of both the native and oxidised (atherogenic) forms of low density lipoproteins (LDL) were compared using neutron and $\mathrm{x}$-ray solution scattering. Neutron data in ${ }_{2} \mathrm{H}_{2} \mathrm{O}$ solutions showed that native LDL is well represented as a quasispherical structure, while x-ray data showed that the internal structure of LDL has lipid in the core and apo-B100 protein and phospholipid headgroups on the surface. When LDL oxidation was induced using a ratio of $6.4 \mu \mathrm{M} \mathrm{Cu}{ }^{2+}$ to $1 \mathrm{mg} / \mathrm{ml}$ LDL protein, structural disintegration of LDL was observed in the scattering curves over a 72 hour period. This disintegration was parallelled by an increase in the $R_{G}$ and $I(0) / C$ parameters observed by neutron and $X$-ray Guinier analyses, and changes in the concentric shell-like structure of the lipids in the core as observed in the distance distribution functions. Structural changes included the aggregation and degradation of LDL, as confirmed by subsequent SDS-polyacrylamide gel elctrophoresis. These changes occurred after the antioxidant content of LDL had been fully depleted.

\section{INTRODUCTION}

LDE is the particle which transports cholesterol to tissues of the body for membrane synthesis and steroid hormone production. The oxidation of LDL has been shown to play a key part in the initiation and progression of atherosclerosis [1-3]. The mechanism of oxidation is most likely to be due to attack by free radicals generated from the metabolic activity of various cell types [4-5] and/or lipoxygenase activity [6-7]. The oxidation process may be mimicked in vitro by $\mathrm{Cu}^{2+}$ ions alone. Once the antioxidant defences of tocopherols and carotenoids have been depleted, oxidation of the polyunsaturated lipids occurs. This sets off a chain reaction of lipid oxidation followed by protein modification. At this stage, modified LDL is taken up in an unregulated manner by the scavenger receptors on macrophages in the artery wall. This leads to accumulation of lipid and the start of the fatty streak, from which advanced atherosclerotic plaques may develop.

Much of the biochemical sequence of events which occur during oxidation and uptake by macrophages has been established. There has been little work to date on the structural changes in LDL during 
oxidation. Solution scattering techniques are an ideal way of looking at this. Before this could be done, native IDI had to be characterised with respect to $\mathrm{X}$-ray solution scattering at the synchrotron radiation source (Daresbury) and neutron solution scattering at the ILL (Grenoble) and ISIS (Didcot) [8]. Solution scattering techniques could then be applied to look at structural rearrangements within LDL during oxidation.

\section{NATIVE LDL BY NEUTRON SCATTERING}

Native LDL was studied by neutron scattering using buffer solutions in $100 \%$ ${ }^{\mathrm{H}_{2} \mathrm{O}}$ in order to reveal its structure under conditions of high negative solute-solvent contrast [8]. The 80\% lipid content of LDL contributes maximally to the scattering profile, and the overall shape of LDL is primarily visualised.

From the low $Q$ region of the scattering curve $I(Q)$ obtained by neutrons, Guinier analyses of the $R_{G}$ and $I(0) / c$ parameters were performed. On extrapolation to zero concentration, the $R_{G}$ values varied between $8.3-9.6 \mathrm{~nm}$, and the corresponding $I(0) / \mathrm{c}$ values also varied across a range. The $R_{G}$ and $I(0) / c$ values from different donors could be linearly correlated with one another. This is interpreted in terms of LDL polydispersity, in which the amount of lipid associated with apolipoprotein $B$ within LDL is not fixed.

Conversion of the scattering curve $I(Q)$ into the distance distribution function $P(r)$ by the Indirect Transformation Procedure (ITP) provides information on the overall dimensions of the LDL. The $R_{G}$ and $I(0) / c$ data obtained from $P(r)$ were consistent with those obtained from Guinier fits. The mean determination of the maximum dimension of LDL was $23.1 \pm 1.2 \mathrm{~nm}$. The position of the single maximum in the $P(r)$ curve was located at $r=9.1-10.9 \mathrm{~nm}$ which is just under half the value of the maximum dimension. The form of $P(r)$ is symmetric about this maximum as expected for a quasi spherical structure.

On the assumption of spherical symmetry in the LDL structure, the $P(x)$ curves were transformed to the radial nuclear density function $p(r)$ in order to obtain information on the internal radial distribution of lipid and protein within LDL. The $\rho(r)$ curves exhibited a region of high negative nuclear density at low $r$ which decreased steadily to $r$ of $7 \mathrm{~nm}$, whereupon $\rho(r)$ levelled out until it reached the outer radius of $13 \mathrm{~nm}$. The initial part of the curve at low $r$ corresponded to the high negative solute-solvent nuclear density of lipids in $100 \%{ }^{\mathrm{H}_{2}} \mathrm{O}$ buffers, from which it is inferred that the lipid hydrocarbons occupy the centre of the LDL core. The low value of $\rho(r)$ at $r$ between $7-13 \mathrm{~nm}$ corresponded to the interpenetration of protein with phospholipid headgroups into the outermost region of the lipid core.

\section{NATIVE LDL BY X-RAY SCATTERING}

Native LDL preparations were characterised by $\mathrm{x}$-ray scattering in physiological buffers. This solvent contrast leads to a much reduced difference in scattering densities between the protein and lipid components. This enables the internal structure of lipid and protein within LDL to be studied, and complements the observation of the overall structure by neutrons.

Using the $I(Q)$ data at the lowest $Q$ values, satisfactory linear Guinier fits could be obtained for over $80 \%$ of the LDL samples. The 

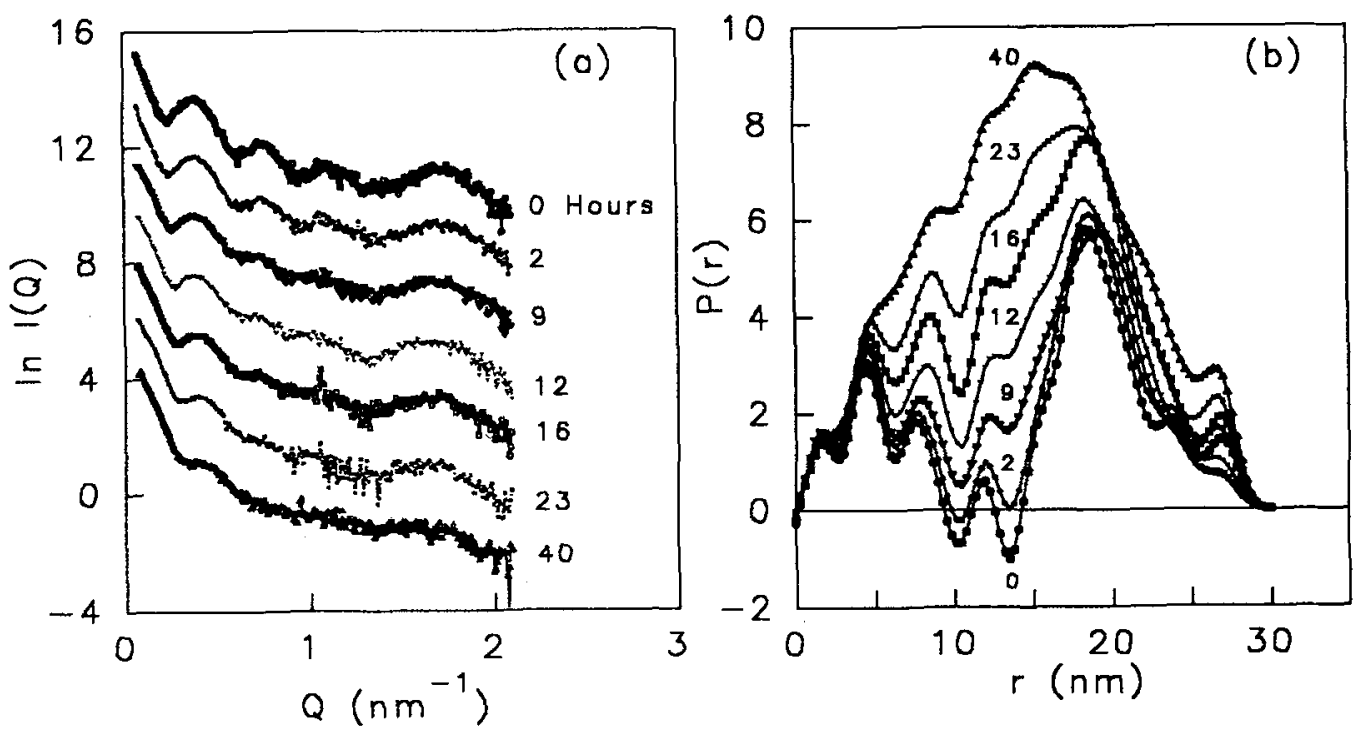

Figure 1

(a) Synchrotron X-ray scattering curves $I(Q)$ at $15^{\circ} \mathrm{C}$ of a single sample of $\mathrm{LDL}$ during $\mathrm{Cu}^{2+}$-induced oxidation. The time in hours after the initiation of oxidation with $\mathrm{Cu}^{2+}$ is indicated.

(b) Distance distribution function curves $P(r)$ of the same LDL sample during oxidation. These were calculated from the $I(Q)$ curves as shown.

$R_{G}$ values at $15^{\circ} \mathrm{C}$ ranged between $12.1-16.0 \mathrm{~nm}$ when extrapolated to zero concentration, and this agreed with previously reported $\mathrm{X}$-ray $R_{G}$ values between $14-18 \mathrm{~nm}$ [9-11]. The larger $R_{G}$ values obtained in $x-$ ray scattering is the result of the different solute-solvent contrast in which the protein component at the surface of the LDL contributes maximally to the $R_{G}$ value. The observed range of the $R_{G}$ values is again attributable to lipid polydispersity in LDL.

The full $X$-ray scattering curve $I(Q)$ can be measured out to a $Q$ of at least $2.1 \mathrm{~nm}^{-1}$ (Figure $1 \mathrm{a}$ ). The $R_{G}$ and $I(0) / c$ values obtained when the full $I(Q)$ data were converted into the $P(r)$ curves agreed well with the values calculated from Guinier analyses. As described in [9], the lipid phase transition in LDE can be monitored by the disappearance of the large submaximum at $Q$ of $1.77 \mathrm{~nm}^{-1}$ at $25-30^{\circ} \mathrm{C}$. The effect of this lipid transition was clearly visible in our $P(r)$ curve between 0-15 $\mathrm{nm}$ where three distinct positive submaxima and two negative submaxima at $15^{\circ} \mathrm{C}$ are transformed into a broad submaximum at $40^{\circ} \mathrm{C}$ [9]. Calculation of the radial electron density function $p(r)$ showed that, at $15^{\circ} \mathrm{C}$, there were four distinct positive and negative peaks at $r$ of $1 \mathrm{~nm}, 2 \mathrm{~nm}, 4.5 \mathrm{~nm}$ and $6 \mathrm{~nm}$ from the centre of LDL [9]. These corresponded to a well-ordered lipid core structure of LDL. At $40^{\circ} \mathrm{C}$ these features in the $P(r)$ curve were replaced by a broad minimum between $r$ of $0-9 \mathrm{~nm}$. At both temperatures, there was a broad maximum at $r=10-15 \mathrm{~nm}$ in $\mathrm{P}(\mathrm{r})$ which corresponded to the protein component.

\section{OXIDISED LDL BY SOLUTION SCATTERING}

Oxidation of LDL was initiated with $6.4 \mu \mathrm{M} \mathrm{Cu}^{2+}$ per $\mathrm{mg} / \mathrm{ml}$ LDL protein at $37^{\circ} \mathrm{C}$. Throughout a time course of 72 hours, the Guinier $R_{G}$ 
and $I(0) / c$ parameters measured by neutron and $x$-ray scattering increased linearly. This indicated that, as the molecular weight of oxidised LDL increased, so did the degree of elongation. This can be explained by aggregation of the LDL particles during oxidation. Further evidence of this was visualised in an SDS-PAGE gel of LDI samples taken at time points during the oxidation time course. As oxidation proceeded, aggregates appeared at a molecular weight larger than that of apoprotein B in addition to LDL breakdown products.

The subsidiary maxima in the neutron and $x$-ray scattering curves $I(Q)$ that represent the quasi-spherical shape of LDL disappeared over the time course of oxidation (Figure 1a). This showed that a more disordered LDL structure had been obtained as the result of oxidative modification. The transformation of the $x$-ray curves into $P(r)$ curves (Figure $1 \mathrm{~b}$ ) assuming a fixed $D_{\max }$ of $30 \mathrm{~nm}$ showed that the electronrich component (visualised by four distinct positive and negative peaks) which represented the core of lipids became more evenly redistributed within the LDL structure during oxidation. The increased $R_{G}$ values are reflected in the increased intensities of the $P(r)$ curves at $r=25-27 \mathrm{~nm}$. Complementary biochemical assays under identical oxidation conditions showed that the $\beta$-carotene (antioxidant defence) content of LDL was depleted and lipid peroxidation occurred before these structural changes in LDL became visible.

\section{CONCLUSION}

Native LDL has been well characterised by neutron scattering. Our synchrotron $X$-ray data on native LDL agrees well with previous X-ray studies of LDL. Both techniques are suitable for study of the effect of oxidation on the LDL structure. Large changes in both the protein and lipid components of LDL as well as in its overall structure can be detected by these means, and these are currently under study.

\section{ACKNOWLEDGEMENTS}

We acknowledge generous financial support from Smith-Kline Beecham, the Wellcome Trust and the Science and Engineering Research Council, and useful discussions with our collaborators, Dr K.E. Suckling and Dr P.H.E. Groot.

\section{REFERENCES}

[1] Parthasarathy, S., Steinberg, D. \& Witztum, J.L. Annu. Rev. Med. 43 (1992) 219.

[2] Witztum, J.L. \& Steinberg, D. J. Clin. Invest. 88 (1991) 1785 .

[3] Schumacher, M., Eber, B., Tatzber, F., Kaufmann, P., Esterbauer, H. \& Klein, W. Lancet 340 (1992) 123.

[4] Bedwell, S., Dean, R.T. \& Jessup, W. Biochem. J. 262 (1989) 707.

[5] Halliwell, B. Br. J. Exp. Path. 70 (1989) 737.

[6] Oleary, V.J., Darley-Usmar, V.M., Russell, L.J. \& Stone, D. Biochem. J. 282 (1992) 631.

[7] Rankin, S.M., Parthasarathy, S. \& Steinberg, D. J. Lipid. Res. 32 (1991) 449.

[8] Meyer, D.F., Nealis, A.S., Bruckdorfer, K.R. \& Perkins, S.J. (1993) manuscript in preparation.

[9] Laggner, P. \& Müller, K.W. Quart. Rev. Biophys. 11 (1978) 371.

[10] Bellamy, M.F., Nealis, A.S., Aitken, J.W., Bruckdorfer, K.R. \& Perkins, S.J. Eur. J. Biochem. 183 (1989) 321.

[11] Atkinson, D., Small, D.M. \& Shipley, G.G. Ann. N.Y. Acad. Sci. 348 (1980) 284 . 